\title{
Conflicting Health Interventions: Participation in Health in Rural
}

\section{Nicaragua}

Birgit Kvernflaten

Centre for Development and the Environment, University of Oslo, Norway

P.O. Box 1116 Blindern 0317 Oslo, Norway

Phone: 004722858794

Email: birgit.kvernflaten@ sum.uio.no

Word count: 10238

Birgit Kvernflaten is a $\mathrm{PhD}$ candidate at the Centre for Development and the Environment (SUM), at the University of Oslo, Norway. Her research has focused on reproductive health and maternal health in Guatemala and Nicaragua, exploring local perspectives in the context of policies and interventions. Her current $\mathrm{PhD}$ research concerns maternal health among rural women in Nicaragua, in particular the policies and practices in relation to maternal healthcare, and how maternal health interventions encounter local socio-cultural realities. 


\title{
Conflicting Health Interventions: Participation in Health in Rural Nicaragua
}

\begin{abstract}
Nicaragua has a long history of health activism and government policies aimed at achieving various models of participation in health. Drawing on ethnographic research in rural Nicaragua, this article situates contemporary participation within this larger historical and political context and critically explores how participation in health is understood and practised. Contemporary health interventions focus on compliance in their endeavour to improve maternal health. This focus, I argue, creates a productive tension between health seekers' and health workers' understanding of themselves as citizens and the government's attempt at achieving public health aims. My empirical focus is on the brigadistas (community health workers), women, and expectant mothers. I describe how brigadistas work as interlocutors between the government and the people. In this relation, women and brigadistas express expectations of and dissatisfaction with the healthcare services offered. Drawing upon an extensive literature on participation, I suggest that within this particular relational space a new political space may appear where demands for improved healthcare services can be articulated and recognized.
\end{abstract}

Keywords: Nicaragua; participation; health system; maternal health; community health workers 


\section{Introduction}

The concept of participation is well embedded in mainstream health discourse, although tensions between utilitarian models of participation and models that focus on change in power relations continue (Morgan, 2001; Rifkin, 2009). Community participation in health emerged as a radical and transformative concept in the 1970s. As part of the era's broader progressive political discourse, participation implied that to achieve change, it was necessary for development practitioners to work with the intended beneficiaries (Batliwala, 1994; Cleaver, 1999). The 1978 Alma-Ata Declaration emphasized participation as an empowerment tool whereby people could articulate and gain decision-making power over their health needs. Community participation facilitated by community health workers (CHWs) became the key principle of primary healthcare (PHC) (Rifkin, 1996). In Latin America, these ideas were incorporated into political discourses about health in virtually every country (Morgan, 1993). By contrast, along with the more 'selective' interpretation of PHC that displaced Alma-Ata in the 1980s, participation became a way of mobilizing community resources to supplement or implement health services more effectively or less expensively (Cueto, 2004; Rifkin, 1996). These programmes, I suggest, also constitute participatory spaces where the focus is on the individual and the individual's ability to govern their own access to care rather than relying on the state. Corbridge et al. (2005, p. 6) have named this shift 'new technologies of rule'. Participation, they argue, along with accountability, human rights, decentralisation, democratisation etc., have become new watchwords in discourses that promise to reduce poverty and improve quality of life by good governance. People are even encouraged to voice their experiences of being poor and what they might need from government institutions (Corbridge et al., 2005, p. 77). Importantly, Corbridge et al. (2005) argue that these technologies of rule are not always to succeed, nor always to fail, or secure state domination over its people. State strategies are also dependent upon how health workers and women 
interpret, engage with them and put them to use. As I show in this article, people understand, contest and rework state strategies that possibly create, I will suggest, a constructive tension between progressive ideas and utilitarian considerations of participation.

This article critically explores participation in health in rural Nicaragua, and how brigadistas $(\mathrm{CHW})$ juggle these tensions between proclaimed health activism and these new 'technologies of rule' in the local health system. Nicaragua has a long history of health activism and governmental policies focusing particularly on participation. The current government embraces Nicaragua's revolutionary ideology, a legacy inherited from the 197080s. This legacy expresses participation and decision-making as a crucial building block of citizenship. There is also a strong focus on involving and using community resources to implement maternal health programmes effectively, as well as enhancing community compliance to these programmes. To understand participation in health and the possible tensions that may arise, we need to situate the idea of participation within people's general expectation of governmental services, local understanding of what participation in general entails, and importantly, local expectations of government responsibility. Focusing on the role of brigadistas and local women's perception of healthcare services, the article shows how tensions arise in the spaces between the government's revolutionary rhetoric and request for community participation in maternal health, and the health system's failure to live up to people's expectations. Within this particular relational space and tensions that occur, women and brigadistas negotiate and express expectations and dissatisfaction with healthcare services offered. By looking at such negotiations as a form of participation, I suggest, may reveal new political spaces where women and brigadistas' voices can be recognized and improved health care can be articulated.

\section{Analytical and methodological approaches}


My analysis draws on five months of fieldwork in a rural municipality in the mountainous areas of Matagalpa, Nicaragua in 2012, informed by reproductive health research and presence in Central America over nearly a decade. The inhabitants in this rural municipality consisting of about 186 communities in various sizes are of mixed white and indigenous heritage (mestizo). Poverty and unemployment are widespread, and many depend on seasonal income from coffee harvest. The empirical research that this article draws upon has focused particularly on policies and practices of the health system in relation to maternal healthcare and state health interventions, and the relationship between the health system and brigadistas, women, and their families. To describe the dynamics among the various factors that influence women's and brigadistas' participation in the healthcare system, this study draws on participant observation as a key methodological tool, yet also draws on more formal interviews and multiple conversations with key informants and local actors. Furthermore, it has included an extensive review of national literature, media, government documents, health policies and plans, including a thorough analysis of the government's participation ideology and policy. This approach has enabled me to place policies and practices within broader political, economic, and historical forces shaping lives and contemporary political circumstances.

I conducted formal interviews with eleven local NGO representatives and four municipal politicians, and five interviews with local hospital personnel and with four women working at the casa materna (maternity waiting home). I went on nearly 30 field trips to different communities and barrios (neighbourhoods - around the municipality's main town). Particularly important to this study was my participation in five brigadista training sessions at health facilities, and my attendance at one municipal assembly designed for community participation, arranged by the municipal government to provide information of public importance and to listen to people's opinions. Furthermore, I conducted open-ended 
interviews with 72 women and men (predominantly women) from 28 communities and barrios, and with 15 brigadistas (including three male brigadistas) and parteras (traditional birth attendants), seven of whom I also accompanied in their work. I have aimed to talk to a wide range of people to understand different perspectives and different actors' views, and furthermore to uncover the complexities of maternal health policies and practices. While participation is a key concept promoted in government policies and plans, my main interest was how participation works in practice, and how people understand and perceive the concept and the process.

\section{Participatory spaces in health}

Public health scholars often refer to participation as an intervention to improve health, with local communities as target groups (Rifkin, 2009). In this article, I take a social scientist's approach to participation, understanding participation as a political and social process (Morgan, 1993; Muller, 1991; Nading, 2013; Rifkin, 2009). Participation is highlighted as one core dimension of citizenship involving responsibilities/duties as an active citizen, as much as it involves rights to inclusion in affairs of common concern to the community (Stokke, 2013). This rights/duty 'contract' between the state and its citizens is vital for the functioning of a democratic state. Public health is an important part of such a 'contract.' Insofar as the state is recognized by its practices, public health is vital to the construction and visibility of the state as a protector of its citizens (Roalkvam \& Jani, 2013). Citizenship thus finds its expression in public health through health programmes designed to improve the health of the population. Importantly, however, there is an inherent paradox in public health. Public health is primarily concerned with the health of the whole population, rather than with the health of the individual (Childress et al., 2002; Kass, 2001). As Childress and colleagues (2002, p. 170) put it, 'public health activities are generally understood to be teleological (end-oriented) and 
consequentialist - the health of the public is the primary end that is sought and the primary outcome for measuring success.' In this endeavour the government or its health authorities needs citizens to comply. The government's use of its powers raises important questions, particularly about the justification for and limits of governmental coercion and citizens' participation and choice, even though the endeavour is benign. There are thus ongoing tensions, productive I will suggest, between public health aims, and people's rights and participation, as these relationships are both dynamic and negotiable (Nading, 2013; Renedo \& Marston, 2015).

I find Cornwall's (2002) concept of 'invited spaces' particularly useful, as health programmes and health services can indeed be regarded as invited spaces. Here, spaces are understood as lived spaces in which participation takes place, while the more metaphorical qualities of the concept provide insights into the dynamics and dimensions, relations and power relations, of participation (Cornwall, 2002). Invited spaces, according to Cornwall, are spaces within which citizens are invited to participate by various authorities (e.g., governments or NGOs). Invited spaces may be transient or regularized, such as random consultations or regular community councils. Invited spaces differ from spaces that are 'claimed' or demanded through actions from below (Cornwall, 2002, 2004; Gaventa, 2004). By seeing the community health workers (CHWs) not primarily as a healthcare provider, but rather as an advocate for the community and an agent of social change (Lehmann \& Sanders, 2007), we may in fact argue that they are placed precisely in order to create such an invited space. CHWs have been consistently used, not only in Nicaragua, but also throughout the developing world as a key element in community healthcare. The use of community members to provide basic health services to the communities has been seen since the 1950 s, but interest flourished in the years around Alma-Ata Declaration within progressive ideas of participation 
(Lehmann \& Sanders, 2007). David Werner's description of the health worker as 'liberator' rather than 'lackey' (Werner, 1981) reflects the belief in the possible agency of CHWs.

The concept of invited spaces is thus useful for two reasons. First, it provides a helpful focus for exploring how participation and practised citizenship may develop, in terms of engagement and regarding whose interests such participation may serve (Gaventa, 2004). Second, it makes explicit the shape of a particular citizen-state relationship. As Das and Poole (2004) remind us, people perceive and experience the state through its practices. Considering such practices encompasses understanding the tension between governance structures that produce and manage the temporal, social, and physical aspects of invited spaces, and participants' potential agency to re-shape these spaces [my emphasis] (Renedo \& Marston, 2015, p. 491). Community participation ideally entails the right of people to be involved in decisions that affect their lives. It is then important to consider community members' perceptions and experiences, and how participatory programmes in practice support such a right (Rifkin, 2009; Roalkvam, 2014; Robins et al., 2008).

To understand such tensions in the public health enterprise, and how brigadistas juggle and negotiate the tensions within participatory spaces on the ground, we must situate the idea and practices of participation within different histories and ongoing political processes (Hickey \& Mohan, 2004). The contradictions between utilitarian considerations of participation and the focus on change in power relations I suggest create productive tensions within which new participatory political spaces can emerge (Cornwall, 2004; Webster \& Engberg-Pedersen, 2002). The progressive Nicaraguan social policies from the 1979 revolution and those that followed in the 1980s have, I argue, returned and been revamped in a new rhetoric shaping people's expectations of current state and governmental practise, and appear as vital political instruments in holding the government accountable. 


\section{Citizens' expectations: a responsible state caring for the poor}

Nicaragua's current health system builds on progressive and radical values such as equality, popular organization, and participation - values stemming from the 1979 socialist revolution when the Sandinistas overthrew the Somoza dictatorship that had oppressed the populace for over 40 years (Lancaster, 1994). The revolutionary Sandinista government saw the health system as politically significant, essential to state construction and to relations between state and citizenry (Bossert, 1985), and publicly committed to the ideal of free healthcare and health as a right.

Brigadistas have throughout been central in building citizenship and enhancing participation. Brigadistas were key policy tools in the campaigns initiated in the early 1980s to reach remote communities and to encourage local community involvement in health (Scholl, 1985). During the revolution healthcare provision improved, and the revolution became a symbol of socio-economic, health, and gender equality. Yet, during and after the revolution, debates about both the politics and practises of the Sandinistas, or FSLN (Sandinista National Liberation Front), surfaced frequently. The use of mass organizations for mainly enforcing FSLN policies rather than encouraging grassroots democracy, was questioned (Vanden \& Prevost, 1993). The transformation of gender relations in the family and society was also debated (Babb, 2001). The level of actual community participation in health from below was likewise up for debate (Barrett, 1996). While the community participation model in health never completely became a bottom-up system, it did nonetheless involve significant lay participation (Tesler, 2006, p. 454).

After the FSLN's 1990 electoral defeat, the newly elected government, influenced by neoliberal politics, implemented a series of structural adjustment programmes. These resulted in extensive decentralization processes, leading to privatization, and to a decrease in healthsector spending and personnel (Birn et al., 2000). Reforms sought to decentralize governance 
responsibility and increase local participation in health system governance. The first postSandinista health plan, written in 1990 , sought to retain a focus on community participation and equity (Birn et al., 2000). However, Birn et al. argue that privatization and budget-cutting within the health system greatly diminished the potential to improve health system responsiveness in Nicaragua.

Yet the recruitment and training of brigadistas persisted in the 1990s. But contrary to the envisioned community participation approach of the Sandinistas, Tesler (2006, p. 455) argues, the brigadistas became an unpaid labour source that lacked the opportunity to launch initiatives or report on necessary health services and needs. By 2002, the community participation model was thus only a skeleton, yet much of the health staff trained during the Sandinista era still embraced the ideal of service to their local communities (Tesler, 2006, p. 459). The National Health Policy and Plan (2004-2015) emphasized the importance of participation to make health investments more effective and efficient, yet also acknowledged the lack of a clear strategy to include the population's experiences to improve health (Ministerio de Salud, 2004a, 2004b). However, Nicaragua's political transformations, from socialist revolution to neoliberal policies, have great implications for the ideologies and the design of the current Nicaraguan government's policies, and thus also for shaping citizens' expectations and participation.

In 2007, the FSLN, led by Daniel Ortega, returned to power, and proclaimed itself a government of the poor that promised to represent and defend the 'marginalized' (Guevara, 2014). When Ortega took power, hope for health reform was high (Nading, 2013). The FSLN has implemented social programmes, such as eliminating fees for healthcare, and more funding for the health ministry was promised - all aiming in part to fulfil the promise made to help the poor and provide equitable access to healthcare (Guevara, 2014; Kampwirth, 2011; Nading, 2013). Ortega revamped public health campaigns as luchas populares (popular 
struggles) (Nading, 2013). Driven by the legacies of the revolution, the idea of participación ciudadana, 'citizen participation' was reintroduced as 'mobilization from below,' with its slogans El Pueblo Presidente (EPP!), 'The People as President/the people govern,', poder cuidadano, 'citizen power,' and la restitución de derechos, 'the restitution of rights.' Such slogans are communicated through various channels - from state documents, policies and strategies, and public political speeches to banners and posters at community meeting points. The government has its own website, Facebook page, and Twitter account all named $E l$ Pueblo Presidente. FSLN's black and red colours decorate city walls, private houses, electricity poles, and bus stops proclaiming DANIEL, daily reminding residents of the FSLN's project. These slogans are a constant reminder of the government's visions and aims that shape citizen expectations of a responsible state caring for the poor.

However, critics or opponents question the FSLN's socialist credentials, including the governments' citizen power and participation project. While retaining the rhetoric of the revolution, FSLN also enforces free trade agreements, allies with the political right and the Roman Catholic Church (Heumann, 2014). The government has not substantially changed the neoliberal model and economic strategies that it inherited from the previous neoliberal governments (Guevara, 2014). Thus, critics argue, the government pursues more neoliberal and Christian values than socialist. Equally, FSLN actively proclaims women's rights, building on revolutionary symbols of gender equality. Yet the government is also criticized for pursuing anti-feminist policies and thus preserving conservative gender roles within the family and the society (Heumann, 2014; Kampwirth, 2011).

Despite their self-presentation as a government of the poor, the government has been criticized for lack of meaningful action towards solving the country's social and economic problems (Guevara, 2014). Concerning participation, critics mistrust the government's attempt at transferring power to the local level and its intention to set up community councils. 
Inspired by the CDSs (Sandinista Defence Committees) from the 1980s, the FSLN introduced Consejos de Poder Ciudadano (CPCs), Citizen Power Councils in 2007, yet from 2013 these were changed to be Gabinetes de la Familia, la Comunidad y la Vida (Councils of Family, Community and Life). Critics question whether the government in fact established these councils to control its citizenry and family life, to promote citizens' protagonist role, and to exploit citizens' participation for the party's interests and objectives, rather than to create genuine participation from below (Aburto, 2013; Rogers, 2013; Romero, 2010). However, in a country as polarized and politicized as Nicaragua, different groups and individuals interpret these political contradictions very differently.

Nevertheless, by representing itself as a government for the poor and endorsing kinship with the revolution, Ortega's government does, as Guevara (2014) also argues, convey the hope that the poor can depend on government institutions for assistance and support. Such hope creates expectations as to the role and responsibilities of the state in relation to the healthcare system. Thus, the Nicaraguan government is caught up in these shifting policies, between 'power to the people,' opportunistic politics, and neoliberal ideas and influence. These shifting and conflicting policies create a particular form of tension within the 'invited spaces' that affects participation on the ground, accountability, and state responsibility.

\section{Local perception on accountability}

The FSLN government holds strong values of the importance of citizen power and participation. Thus, the government has installed several participatory spaces in local communities. Cabildos abiertos ${ }^{1}$, open municipal assemblies with attendants from the

\footnotetext{
${ }^{1}$ Cabildos Abiertos are legacies from colonial times, revitalized during the revolution to consult upon and give legitimacy to draft the new constitution in the 1980s. Today they are to function as open municipal assemblies arranged by local governments to inform, consult upon and include people in decision -making.
} 
municipalities' communities, are one such space. The CPCs in local communities are another. The brigadistas in local communities, used by the government to facilitate participation in health matters, are yet another. Such spaces, as well as the communication of citizen power and participation, form what Cornwall (2002) has named 'invited participatory spaces', because they are produced, formed, and managed by the government. These structures communicate local residents' rights and opportunities to participate in matters that concern their community, and as I will argue, increase perceptions of participation amongst local residents as receiving state services.

At the one cabildo I attended during fieldwork, huge banners displayed the following message in the stadium where the event was held: [El municipio] ejerciendo la democracia participativa convirtiendo la participación en poder y la consulta en decisión. '[The municipality] is practising participatory democracy and converting participation into power and consultation in decision-making.' The local government made its intention in hosting this meeting quite explicit. Alcaldía, the mayor's office (FSLN), hosts cabildos twice a year in the main town in this predominantly Sandinista municipality ${ }^{2}$. The cabildo I attended in February discussed previous community projects with the aim of rendering clear and transparent accounts to the people, whereas the second cabildo, held at the end of each year, discusses future projects. Although the stadium could accommodate several hundreds, only 150 people were present out of the municipality's approximately 67,000 residents - a mix of local politicians, NGO representatives, brigadistas, parteras from the casa materna, and women and men from communities in the municipality were present. The local radio station communicates when such events are about to happen. Most people arrived around 11 a.m. to the meeting scheduled for 9 a.m. The mayor talked about the projects implemented in the

\footnotetext{
${ }^{2}$ Although the majority will define themselves as Sandinistas, there are differences as to whether people are convinced danielistas supporting Daniel Ortega, positive to FSLN (if not Ortega), or more resigned rather identifying themselves with the revolutionary Sandinismo. Yet all have probably voted for Ortega.
} 
communities during the past year - roads, electricity, latrines, roofing, etc., and about the local hospital and the casa materna's accomplishments. Nobody asked questions in public.

As the mayor was speaking, a man sitting next to me leaned over and whispered: 'Some sit in the front and applaud hard, but only because they got their project funded'. He gave me a rather dejected smile and walked away. After the cabildo I was left with this man's words, and with questions regarding how people actually participated in and perceived these events. To my question about why so few people showed up for the cabildo, a brigadista - a Sandinista - replied that most people did not get their projects funded last year so they did not go. Likewise, perhaps not so surprisingly, a liberal ${ }^{3}$ politician claimed that people do not attend because the local politicians do not listen. An older Sandinista, a man from one of the town's barrios working in the campo (countryside) uttered: 'I have to work, and they do not listen anyway, so I don't go.' I later learned that there were internal conflicts within the local FSLN government because Ortega had put in place a new Sandinista mayor, against the wishes of the majority of the local residents. This conflict negatively influenced people's relationship with the mayor's office. I understood however, that low attendance at the cabildo was due to locals' scepticism that the local government would listen to people's needs for various projects in their communities.

In addition to the cabildo, local FSLN representatives were clear about how CPCs provide possibilities for expressing opinions and needs, and how local residents, through the CPCs, can apply to the mayor's office for projects. 'It is a participatory process,' one representative claimed. In interviews, they boldly described the successes of these councils in local communities. According to these local politicians, every community had a CPC consisting in theory of 16 members (including the brigadista typically representing health in these councils). 'As such the communities participate' they assured me. In contrast, in the vast

\footnotetext{
${ }^{3}$ The 'liberals' are fractured into several parties today all of which claim general adherence to the traditions of the historical liberal movement in Nicaragua (Wilm, 2011, p. 4). Local residents generally defined it as being in opposition to FSLN.
} 
majority of the communities and barrios I visited, brigadistas and local residents claimed that the CPCs are not working. 'The idea is that the CPC will see the needs of the people. Like the plan techo [governmental roofing project], but it is not working, mainly because people do not see results', uttered a female Sandinista brigadista from one of the barrios close to the municipality's main town. Like many brigadistas, she could not see how it contributed to her barrios' (tangible) needs. Visiting communities and barrios and asking how the CPCs functioned revealed that, although the government presents the CPCs as places for participation, as does the cabildos, local residents do not believe that these institutions are capable of meeting the needs of the people.

The political persuasion of both local FSLN and liberal politicians influenced how they described ideas and practices in the municipality. Between Sandinista and liberal brigadistas (there are both) and local residents, the lines were blurrier. Liberals in general claimed that government projects go mainly to Sandinista communities or to Sandinista families within communities. Yet Sandinista communities, also worried constantly about what projects they might receive, if any. In the majority of the communities and barrios, local residents uttered dissatisfaction regardless of political persuasion, 'All the projects go to other communities, not ours,' people often said.

In discussions with local residents on the meaning and content of participation, they frequently referred to participation as receiving help, notably from the (local) government. 'Participation means providing projects to the poor, like food and housing,' said a 21-year-old woman living in a small, poor house on the outskirts of the main town, with a Sandinista flag painted on the wall, when I asked her what 'participation' meant to her. Likewise answered a 27-year-old woman from a barrio close to the centre of the town; 'Participation means organizing, and help where people live. It has two parts: giving help, and receiving help - and they should agree.' She as well made clear she was a FSLN supporter, and continued arguing 
that with Ortega in power communities could receive more help. Whereas some interviewees, such as the women quoted above, had clear opinions about the meaning and content of participation, others found the subject harder to articulate. However, while discussing participation, women regularly expressed views regarding community organization and decision-making. These women regularly expressed that, in poor communities, organizing the community to decide what they need was essential if they were to gain ayuda 'help' and proyectos 'projects.' As one remarked 'somos muy pobres' - 'we are very poor' - they have few other means to improve their quality of life. An older female brigadista expressed similar concerns in a training session at the hospital and provided an account of what participation meant to her. 'The institutions will listen to us on what we [the community] need and [will] provide more help,' she explained, and continued to talk about how participating also provides opportunities for communicating health problems and needs to the hospital. She was convinced that if the community was organised and participated, more projects would come to the community and government institutions would listen and respond to their needs. While there was general dissatisfaction regarding what projects the communities actually received, these utterances also reveal hope of what participation might or should provide.

The government's invitation to participate in matters that concern their community, I hold, creates such hope. Local residents understand this invitation and the concept of participation to be about projects and services from the government, and the way that those can respond to people's stated needs. These participatory spaces however remain contested and conflicting. These participatory practices reveal the entangled ideologies and messages of the government; it presents participation as 'power to the people', yet people in the communities and barrios contest their actual part in decision-making. Guevara (2014) refers to such conflicts or struggles as government or public performance displays, in which he argues that the government creates the impression of caring about the people, and how 
participatory democracy remains an illusion. Yet, I will suggest that these displays are not empty of meaning or practise. On the one hand, these displays express a willing government attending to its citizenry. On the other hand, they reveal political disagreements, power relations, resistance and mistrust, and they thereby shape a political debate concerned with citizens' expectations and the government's ability to deliver on its slogans. How participation become about ensuring a fit between needs and services offered, and of the discrepancies that exist within these spaces, provide a basis for understanding the expectation of state deliveries in health.

By focusing on participation in health particularly, in the following sections I further explore the discrepancy between citizens' expectations and the state's ability to deliver. I explore the ostensible conflict between citizens' rights and compliance in health, and show the dissatisfactions that arise from the health system's failure to live up to people's expectations. While participation through cabildos and CPCs perhaps remain an illusion, interestingly in health I suggest, the conflict and tensions arising in the participatory spaces reveal a political space where brigadistas and local women may negotiate healthcare needs.

\section{Participation in health - the role of the brigadistas}

The brigadistas are local health representatives and should facilitate participation in health. Yet, the brigadistas' work involves conflicting roles as representatives of both the local community and the health ministries. The brigadistas embody somehow the ideology of citizens' rights in decision-making while simultaneously expected to endorse compliance in government health schemes. They are crucial in the local health system. MINSA (Ministry of Health) provides primary healthcare through health centres/primary hospitals and health posts in rural communities; but as the health system lacks the capacity to reach people in all remote communities; its reach is highly dependent on the work of brigadistas. According to health 
educators at the local hospital, since the FSLN returned to power, the government has reemphasized working with the communities and brigadistas: La unidad hace la fuerza, 'unity is strength,' demonstrating the revolutionary and socialist vision of the brigadistas' role.

More than half of the 186 communities in the municipality had at least one brigadista, both in Sandinista and liberal areas. The community, often with assistance from hospital health educators, selects a brigadista, some are recruited by another brigadista, or inherit the role from family members. Brigadistas should carry out various 'basic health' tasks, including teaching household hygiene, encouraging vaccination, etc., though their main focus is on identifying and visiting pregnant women, gathering data about these pregnant women, and encouraging institutional childbirth.

One of the government's top health priorities is to reduce maternal mortality. In aligning governmental policies to the global Millennium Development Goal 5 on improving maternal health ${ }^{4}$, the Ortega government made institutional childbirth the most important intervention. The focus on institutional deliveries has led to considerable pressure on health workers and brigadistas to make women comply with this governmental objective (Kvernflaten, 2013). Health professionals thus push brigadistas to make women and birthing mothers comply in order to reach targets set of global and national policy agendas, while at the same time, communicate the brigadistas' work and role as situated within a revolutionary agenda of citizen power.

In brigadista monthly training sessions at the local primary hospital opened in 2011, or at one of the eight health posts in the municipality, health educators, doctors, and nurses reveal this conflicting role of brigadistas. One the one hand, health professionals place brigadistas' work within progressive and radical revolutionary values. In the training sessions, this is expressed in the vocabulary of the Sandinista such as love, solidarity,

\footnotetext{
${ }^{4}$ The proportion of deliveries assisted by a skilled birth attendant (SBA) has become the main performance indicator for measuring progress on MDG 5. During fieldwork, about 30-50 per cent of women in the study area gave birth at home.
} 
voluntarism, goodwill and socialism. 'What we always have to carry with us is love, care and affection,' one health educator expressed to the brigadistas, and continued; 'this country is developing because of voluntarism and goodwill'. A nurse entering one training session focused on the same principles. 'We acknowledge your challenges. We have salary, you don't. We work in the cool shadow, you under the hot sun. But remember, your work is about love and solidarity with our people and the communities', she clarified to the brigadistas. Against this backdrop, health professionals pointed out that brigadistas are the communities' way of participating and through participation improve the communities' health situation. By further promoting people's rights to healthcare - the restitution of rights - both verbally in these meetings and written on posters at the hospital and health posts, the health professionals gave the impression of viewing brigadistas and people as citizens who enact their rights through participation in health.

Yet on the other hand, health professionals identified in detail and explained what brigadistas need to do to improve health, and to organize and participate 'properly'. One of the main themes in the training sessions was maternal health. Here health educators and nurses taught brigadistas how to raise awareness, train in Plan de Parto (safe motherhood plan), organize the community, identify, register, and refer pregnant women to hospital care, and follow up and evaluate these tasks. The health educator hosting one of the sessions stated; 'those [brigadistas] who visit pregnant women and fill out la ficha de plan de parto ${ }^{5}$ [the woman's birth plan] are doing a good job, those who do not are weak'. Health educators focus on very detailed and specific tasks that brigadistas should perform in their community in order to achieve health goals, maternal ones especially, stressing that to reduce maternal mortality, no woman should give birth at home, because of potential complications. Within

\footnotetext{
5 This plan includes number of antenatal check-ups, who attend the birth and where, danger signs in pregnancy and birth, the importance of saving money for the birth and arrange transport option to the hospital in emergencies, The vast majority of women did not have such written plan, partly due to lack of copies to be distributed.
} 
this mode of practice, the brigadistas' role was to urge expectant mothers to comply with the government's health interventions in the communities.

Brigadistas thus balance and manage these different roles. They are both the people's health workers who should attend to community needs, and the long arm of the government in its effort to reach centrally defined health goals. Thus, brigadistas work as interlocutors between the state and the people, as a government health representative and as the community's health representative and 'voice.' Nading (2013) also shows how brigadistas mediate a role between responsibilities towards the state and entitlements on the behalf of the community. Health professionals repeatedly express to brigadistas how dependent they are upon their work, thus indicating the brigadistas' responsibility in working with the government in improving health. In my conversation with one health educator, he repeatedly confirmed the importance of the brigadistas' work, and that health educators therefore work on recruiting brigadistas in all communities. 'We are dependent on brigadistas to work in the communities. Without them we have no information and we will not know anything about what is going on,' he explained. Like the health educator, a doctor working for SILAIS (the regional Ministry of Health) further emphasized the point: 'Without community organization the government's [maternal] health strategies will not work.'

As a representative of the health system, the brigadista walks from door to door, visiting pregnant women and advocating institutional childbirth. Yet as the community's health representative, the brigadista is someone to whom the women can express healthcare needs and concerns. Such communication surely depends upon their relationship; upon how active and present the brigadista is, if there is a brigadista at all. In any event, the brigadista as a mediator provides possibilities of communicating community needs and concerns to the health facilities. Nonetheless in training sessions, health professionals seldom asked brigadistas about local women's own needs or preferences, because 'needs' appeared to be 
already defined. The information asked for was data concerning centrally defined targets. However, the conflict between the brigadista as enacting citizens' rights to participation, and that of the brigadista as implementing health strategies and pursuing goals create tensions in participatory spaces. It is within these tensions, I argue, that the possibility emerges of reshaping participatory spaces through expressions of dissatisfaction and through negotiations relating to unfulfilled promises of improved healthcare services to the poor.

\section{Negotiating participatory spaces}

The mediating role of the brigadista provides possibilities for communicating women's needs and concerns to the health facilities. There was a widely held view among women that healthcare services have improved slightly after Ortega returned to power. Women referred to an increase in medical personnel at the new hospital, improvement in the availability of medicines, and how the hospital prioritizes pregnant women. 'After Ortega came back to power there are more health facilities and they are focusing more on women's health and that no woman should die in pregnancy,' a woman I met in the outskirts of the main town explained. Yet she continued, 'but the care people receive, is not very good'. While high proportions of women recognize some improvements with the opening of the new hospital, poor quality of care remains a major issue to them.

'Healthcare is free, but it might kill you', a man told me one day on my way back to the main town after visiting a remote community. This utterance echoed what many women reported. 'The quality at the hospital is very bad,' an older woman from a poor community explained in frustration. 'They can't find out what is wrong with you, the nurses and doctors come late, they let people wait in extreme pain or tell them to come back another time. Often they give you prescriptions you have to pay for. And everybody just get acetaminophen [paracetamol], no matter the diagnosis.' Although the Sandinista flag was visibly placed on 
the wall of her house, she did not have any concerns criticising the hospital. Another woman I met in a barrio close to the hospital, a 27-year-old woman eight months pregnant, was not happy at all with the care she had received at the hospital: 'I went to the hospital with extreme pain and miscarriage symptoms. I was six months pregnant but I had to wait from 10 a.m. until 4 p.m. Even though they say, they prioritize pregnant women. Luckily, the baby was fine. I have talked to the brigadista in the barrio further down the road about this,' she further explained, 'if she had not persuaded me that the hospital is the best place to give birth, I would not have gone back.' While women certainly appreciate hospital maternal healthcare in many cases, pregnant women frequently expressed frustrations of poor treatment, unpleasant personnel, and long queues, and described how hospital personnel sent them home without consultation. Women also uttered embarrassment at having to spread their legs in front of a stranger during childbirth: some even call hospital birth practices grosería - rude or insulting, referring especially to cutting, stitching (episiotomies) and the cleaning of the woman, indicating that they felt pressured into birthing services they consider inadequate or inappropriate. In many women's opinion however, the government has yet to fulfil the promises of improved healthcare services to the poor.

Women expressed dissatisfaction and frustration in my interviews, but also directly to brigadistas. When on home visits, brigadistas frequently received such complaints. Brigadistas supported and confirmed women's stories of poor treatment and hospital care, but they also simultaneously expressed the importance of going to hospital for antenatal care and delivery. 'The birth is still safer at the hospital,' one brigadista explained to a woman we visited who had experienced a doctor treating her badly. 'Since you still feel pain, I urge you to go back tomorrow for a check-up', the brigadista continued. The woman looked down and mumbled that if she found the time, she would go. When leaving the woman's house, the brigadista complained to me, 'It is not easy, you know, the doctors do not always treat 
women nicely, or even take my referrals seriously, but the women should go to the hospital for delivery in case something goes wrong.' She folded her piece of paper with the woman's name, age and the month of pregnancy as we moved on to the next pregnant woman's house.

In addition to uttering women's concerns, brigadistas also expressed personal stakes and frustrations related to solidarity and volunteerism and pressure to reach health goals. Brigadistas frequently described a feeling of being 'used' by the health system. 'MINSA [the hospital and its personnel] say we are so necessary in the communities and barrios, and that they need us for information, but they do not give anything back. They don't consider our [brigadistas'] needs,' uttered a 46-year-old male brigadista who has been a brigadista since the 1980s and the revolution. Like him, the majority of brigadistas expressed frustrations over not getting anything in return for the work they do. Primarily in terms of the lack of tangibles, credentials or services from the hospital, such as an ID card, a pencil or backpack, or an identifying t-shirt to wear when working. They also lamented, the absence of food aid, and the lack of basic medicines to keep at home such as fever-reducing medicine. 'Things have improved after Ortega returned and he is fulfilling some of what he has said. Just not enough, and not in our barrio,' another older female brigadista explained. She referred to projects in her own barrio, but also the hospital's failure to support her work, and clearly expressed lack of motivation to carry on with her tasks. 'At least we want to be recognized and acknowledged for our work and expertise concerning local matters,' the 46-year-old male brigadista further explained. 'Many of the doctors learn a lot in medical school about theories, but it is on the ground they will learn how it works in real life. The doctors can learn something from the campesinos [peasants] too.' Along the same lines, a male liberal brigadista stated how he found the relationship with the hospital problematic. 'It is like we do not exist when I visit the hospital and they do not recognize our work' he explained. 'But data on the community they want' he continued, obviously upset. His female counterpart looked at 
me and nodded but added that she enjoyed her work as a brigadista. 'I like working for my community,' she uttered. Like her, another female brigadista, a Sandinista, was also pleased with her role as brigadista, yet she also added during a conversation; 'We do this [work as brigadistas] out of love for our community, but it would be nice with some support!' Brigadistas of all political persuasions juggled the dual role of attending to community needs, while working with the health system in its effort to reach government-defined health goals. The extent of dissatisfaction and how brigadistas conceive of their role and practice varies, nevertheless there is a general tendency among brigadistas to want something in return for the work health officials expect them to perform.

\section{Talking back}

Women and brigadistas discuss concerns and frustrations amongst themselves and in meetings. Brigadistas expressed and negotiated both their own and community needs and frustrations with the health system in various arenas; in training sessions at the hospital, directly to health educators or through NGOs. In training sessions at the hospital, I listened to brigadistas communicating women's concerns to the health educators, doctors and nurses hosting the sessions. The brigadistas were never as direct in their speech concerning poor quality of care as they had been during interviews. Yet I listened to brigadistas describe many problems: that women in their communities are reluctant to go to hospital for childbirth; to the difficulties of contacting hospital in emergencies, how the ambulance fails to come, and that brigadistas do not have basic medicines at home. 'People in my community don't think the brigadista is doing a good job because we do not have medicines, and because the ambulance does not come when we call,' an older female brigadista explained in a training session. 'And when I tell the women that they should go to the hospital to give birth they do not listen and say they won't,' she continued. The response she got was something I often heard when 
hospital staff responded to such frustrations, 'The hospital cannot solve all problems even though we want to. The hospital does not have the resources,' a health educator expressed and followed up by urging the brigadistas to keep on visiting women and organizing their community to make women deliver at hospital, simultaneously emphasizing the importance of love, solidarity and voluntarism.

These discussions and negotiations in training sessions made health educators aware of situations, views and experiences in local communities. Brigadistas also stated they could talk to health educators at the hospital about their own as well as women's concerns. 'I have told the health educator how the doctors sometimes stand there talking and drinking soda instead of attending to women,' an older brigadista explained. 'I said that some women do not want to go there [the hospital] because of this,' she continued. Another brigadista had learned from a health educator to write down the name of the doctor or nurse who had treated a woman badly at health facilities. In a visit to a woman with this brigadista, I listened to them discussing and getting to who the doctor was, that the woman referred to as 'odioso,' hateful. 'I'll tell the health educator,' the brigadista confirmed and wrote down the doctor's name. I confronted the health educators about such concerns in interviews, and they confirmed that they received such information. They were well aware that patients experience lack of respect in health facilities and that they needed to work on that problem. Yet it also became clear that health educators further debated and negotiated such information with hospital doctors and nurses. How such information was forwarded and what discussions took place, was dependent upon the individual health educator and the responsiveness of the doctor or nurse responsible for mistreatment.

Frustrations are thus aired both in training sessions and conversations between brigadistas and health educators. A third place I observed frustrations being expressed was through health NGOs working in local communities. These NGOs often work closely with 
brigadistas. At a hospital meeting I attended, a local NGO representative reported brigadistas' and local residents' concerns to doctors and nurses, focusing on the brigadistas' experiences of not being shown respect and lack of support of their work, and MINSA's [hospital] lack of presence in the affected communities. 'Many brigadistas feel that MINSA is not taking them seriously. They feel that when MINSA needs them, MINSA is there, but when they need MINSA, they do not get support,' the NGO representative uttered. 'Brigadistas just want to feel they are part of the system. An ID card as health personnel, at least, may help,' the NGO representative continued. Even though everyone at the meeting wanted to improve community health, the health professionals answered these frustrations by linking them to health system constraints. The doctor in the meeting answered more or less the same way the health educator had replied to the brigadistas in training sessions - the hospital does not have the capacity to reach all communities. The discussion continued around how they can receive better information about pregnant women in the communities, and how they should improve the teaching of brigadistas to report such information. After the meeting, the NGO representative shook his head and complained to me about how health professionals really did not understand or take seriously brigadistas concerns. As Nading (2013) has also shown, the brigadistas continually strive to be recognized and valued by the health system.

During my interviews with health educators, it became clear that they were indeed aware of brigadistas' complaints of not being recognized and acknowledged for the work they do. The health educators lamented the lack the resources and the difficulties in keeping brigadistas motivated. Understanding brigadistas' daily experiences, complex motives, concerns and criticism, is crucial to inform positive relationships among brigadistas, health institutions and communities (Maes et al., 2014). The brigadistas on the one hand, experience that health professionals listen at some point, yet on the other hand, they hold that this does not lead to any effective change. Health professionals as well operate within a health system 
that lacks resources, and they too are under pressure to reach health goals. What they have at hand to motivate the much-needed brigadistas are revolutionary ideas of love, solidarity and voluntarism.

\section{Emerging political spaces?}

As mentioned at the outset of this article, community health workers, such as the brigadistas, are frequently referred to as a key resource for public health, in that they serve as a link between the official health system and its health providers, and local communities. In this article, I have shown how the presence of the brigadistas creates spaces where women and brigadistas can express both expectations to and dissatisfactions with the current health system. This is a space, I suggest, where women and brigadistas potentially can claim their rights to improved healthcare services.

The brigadista embodies somehow the idea of a responsible government caring for its people and serves as a reminder of such a government by his/her very presence, even during periods when the government struggles to live up to these expectations. In addition, the brigadista needs to juggle between his or her conflicting role as a supporter of citizen rights, and the government's demand for compliance, both so salient in all public health interventions. Tensions arise when local residents and brigadistas understand participation to be about social policies and receiving welfare projects such as quality healthcare to the poor. Practice however is contradictory with its focus on mandatory compliance with health interventions - within a health system which local communities simply do find neither satisfactory nor reliable.

Paradoxically, the government uses brigadistas to advocate for maternal healthcare services and interventions, and often brigadistas do so with great success. Although of core value to the official health system, this very system fails to provide brigadistas with 
recognition, status or compensation that correspond with their presumed value. Landers and Stover (2011) argue this to be the case in many health systems involving CHWs. Yet, within this relational space and tensions that occur brigadistas and women express and negotiate expectations and dissatisfaction with the healthcare services offered. People's dissatisfaction and ability to raise their voices, I suggest, reveal a participatory space. This opens up for questioning what constitutes as participation, and how we can go forward to make brigadistas' and women's perceptions and experiences have practical impact.

The government's invited participatory spaces are filled with conflicting ideas and practices, embedded in the government's exercise of its health programmes. While the government proclaims participation as providing local residents with decision-making power, health professionals articulate detailed accounts of what participation should look like in order to reach health goals. Participation in this sense may, to use Corbridge et al's (2005) words, constitute a 'new technology of rule', involving revolutionary rhetoric embedded in a topdown system where responsibility is even put on the brigadistas to comply with strategies and reach health goals. Yet I will argue that participation is never clear-cut top-down (compliance) or bottom-up (empowering). Muller (1991) argues how actors in various positions express participation in many different ways of both support and opposition, such as when citizens, because of poor living conditions for example, demand the state to be included. Participation is on this case a bottom up reaction, a local reaction to policies and politics that shapes their lives (Muller, 1991). The demand for better services and better quality of care raised by both brigadistas and local women is such a bottom up reaction, a demand to the Ministry of Health for decent services. Participation is a dynamic process, even though participation in health apparently seems top-down, there are negotiations up, down and outwards: Between professional health workers on the local and national level, between health workers and brigadistas, NGOs and women. This is how women and community health 
workers understand, rework and contest state policies and strategies (Corbridge et al., 2005), and as such effectively and expressively respond to them.

I thus suggest that we should recognize brigadistas and women's negotiations with the health system as a form of participation. Such recognitions make possible the acknowledgement and appreciation of people's agency, and make possible not only seeing the brigadistas as producers of quantitative health outcomes, but also as advocates for improving quality healthcare services to the poor, also called for by Nading (2013). This matters because it affects the way we think about the government's practices and how we perceive peoples agency. For participation to be successful and for opening up possibilities for reshaping 'invited' spaces to become new political spaces different voices must come through. Depending on how local people mediate and contest state strategies, Corbridge et al (2005, p. 262) argue, technologies of rule, such as how Nicaraguan health governance is played out can, slowly and unevenly, increase poorer people's sense of dignity and might even provide a degree of power over those who govern them. To recognize and support brigadistas' negotiations of dissatisfactions and stated health needs, I suggest, is a first step in the processes towards including people in decision-making regarding their health, in order to shape a political agenda where views and experiences of brigadistas and women are respected and included.

\section{Conclusion}

My main aim in this article has been to show how the Nicaraguan technologies of health governance create productive tensions on the ground, between health system, health workers and women, which have the potential to reveal new political spaces where rights and 
responsibilities in healthcare may be articulated and debated. Drawing upon an extensive literature on participation, I have shown the importance of situating participatory practices in health between governance structures that produce and manage 'invited spaces' and locals mediation and contestations within these spaces, to understand participants' potential agency to re-shape these spaces (Renedo \& Marston, 2015). The recognition and acknowledgment of people's agency and as claimants of rights, requires a responsible and responsive state. This is exactly what the current Nicaraguan government claims to be. Nicaragua has a long history of health activism, and government policies emphasises participation in health as one significant building block of citizenship. However, recent neoliberal restructuring challenges the current political processes motivated by the socialist revolution. In Nicaragua, participatory healthcare is a combination of a radical notion of participation as a vehicle for grassroots advocacy, and a way of mobilizing community resources to supplement or implement health services more effectively or less expensively, even transferring responsibility to access health services onto citizens themselves. Yet revolutionary symbols such as citizen power and invited participatory spaces, not only stimulate people's desire for social change, but also shape citizen expectations of a responsible state caring for the poor, and thus also how participation is understood and practiced.

Arguably, brigadistas embody two conflicting models. On the one hand, the Nicaraguan government's vision of promoting citizen rights through participation in health, and on the other hand, how brigadistas and women are forced into a more compliant role of fulfilling aims and targets. We may argue that this is in fact the model of citizenship and as such the brigadistas embody both rights and responsibilities; both participation and compliance. I will suggest, however, that these relationships and tensions are also informative of how women experience the care they are offered. These experiences also apprise the ongoing debate in maternal health literature on pushing facility birth to reduce maternal 
mortality in weak health systems seen as incapable of providing exactly that, good maternal care. It is precisely the discrepancy between citizens' expectations of quality healthcare to the poor and the (in)ability of the state to deliver, that creates tensions and dissatisfaction.

Although the Nicaraguan health system has shown progress, the government's promises to the poor rural population have remained unfulfilled. While the emerging political spaces are filled with negotiations, persuasions and power imbalances the expectations and dissatisfaction of local women and brigadistas should be recognized as a way of speaking back to power on health needs to which the government should - or must - respond.

\section{Acknowledgement}

My sincere thanks to the many people in Nicaragua who shared their views and experiences with me, and to Sidsel Roalkvam and Katerini Storeng for reviewing drafts and providing valuable and constructive advice. This study was supported by the Centre for Development and the Environment (SUM), University of Oslo, as part of my $\mathrm{PhD}$ thesis.

\section{References}

Aburto, W. M. (2013, November 13 ). La 'democracia directa' de Ortega [The direct democracy of Ortega]. Confidencial. http://www.confidencial.com.ni/articulo/14811/la-039-democraciadirecta-039-de-ortega

Babb, F. E. (2001). After revolution: mapping gender and cultural politics in neoliberal Nicaragua. Austin, TX: University of Texas Press. 
Barrett, B. (1996). Integrated local health systems in Central America. Social Science \& Medicine, 43, 71-82. doi:10.1016/0277-9536(95)00336-3

Batliwala, S. (1994). The meaning of women's empowerment: new concepts from action. In G. Sen, A. Germain, \& L. C. Chen (eds.), Population policies reconsidered: Health, empowerment, and rights. Boston, MA: Harvard Center for Population and Development Studies.

Birn, A. E., Zimmerman, S., \& Garfield, R. (2000). To decentralize or not to decentralize, is that the question? Nicaraguan health policy under structural adjustment in the 1990s. International Journal of Health Services, 30(1), 111-128.

Bossert, T. J. (1985). Health policy: the dilemmas of success. In T. W. Walker (ed.), Nicaragua: the first five years (pp. 347-363). New York: Praeger.

Childress, J. F., Faden, R. R., Gaare, R. D., Gostin, L. O., Kahn, J., Bonnie, R. J., . . Nieburg, P. (2002). Public health ethics: Mapping the terrain. The Journal of Law, Medicine \& Ethics, 30(2), 170178. doi:10.1111/j.1748-720X.2002.tb00384.x

Cleaver, F. (1999). Paradoxes of participation: questioning participatory approaches to development. Journal of International Development, 11, 597-612. doi:10.1002/(SICI)10991328(199906)11:4<597::AID-JID610>3.0.CO;2-Q

Corbridge, S., Williams, G., Srivastava, M., \& Véron, R. (2005). Seeing the State: Governance and Governmentality in India. Cambridge: Cambridge University Press.

Cornwall, A. (2002). Making spaces, changing places: situating participation in development. IDS Working Paper 170. Institute of Development Studies Brighton, Sussex.

Cornwall, A. (2004). Spaces for transformation? Reflections on issues of power and difference in development. In S. Hickey \& G. Mohan (eds.), Participation. From tyranny to transformation?: Exploring new approaches to participation in development (pp. 75-91). London: Zed

Cueto, M. (2004). The origins of primary health care and selective primary health care. Am J Public Health, 94(11), 1864-1874.

Das, V., \& Poole, D. (2004). Anthropology in the margins of the state. Santa Fe, NM: School of American Research Press.

Gaventa, J. (2004). Towards participatory governance: assessing the tranformative possibilities. In S. Hickey \& G. Mohan (eds.), Participation. From tyranny to transformation? Exploring new approaches to participation in development (pp. 25-41). London: Zed.

Guevara, A. (2014). Performance, theatre, and society in contemporary Nicaragua: Spectacles of gender, sexuality, and marginality. Amherst, NY: Cambria Press.

Heumann, S. (2014). Gender, sexuality, and politics: rethinking the relationship between feminism and Sandinismo in Nicaragua. Social Politics: International Studies in Gender, State \& Society, 21, 290-314. doi:10.1093/sp/jxu004

Hickey, S., \& Mohan, G. (2004). Towards participation as transformation: Critical themes and challenges. In S. Hickey \& G. Mohan (eds.), Participation. From tyranny to transformation?: Exploring new approaches to participation in development (pp. 3-24). London: Zed Books.

Kampwirth, K. (2011). Latin America's new left and the politics of gender: lessons from Nicaragua. New York: Springer.

Kass, N. E. (2001). An ethics framework for public Health. American Journal of Public Health, 91(11), 1776-1782. Retrieved from http://www.ncbi.nlm.nih.gov/pmc/articles/PMC1446875/

Kvernflaten, B. (2013). Meeting targets or saving lives: Maternal health policy and millennium development goal 5 in Nicaragua. Reproductive Health Matters, 21(42), 32-40. doi:10.1016/s0968-8080(13)42728-3

Lancaster, R. N. (1994). Life is hard: machismo, danger, and the intimacy of power in Nicaragua. Berkeley: University of California Press.

Landers, S. J., \& Stover, G. N. (2011). Community health workers-Practice and promise. American Journal of Public Health, 101(12), 2198-2198. doi:10.2105/AJPH.2011.300371

Lehmann, U., \& Sanders, D. (2007). Community health workers: What do we know about them? The state of the evidence on programmes, activities, costs and impact on health outcomes of using community health workers. Geneva World Health Organization (WHO). 
Maes, K., Closser, S., \& Kalofonos, I. (2014). Listening to community health workers: how ethnographic research can inform positive relationships among community health workers, health institutions, and communities. Am J Public Health, 104(5), e5-9. doi:10.2105/ajph.2014.301907

Ministerio de Salud. (2004a). Plan Nacional de Salud 2004-2015. MINSA. Managua, Nicaragua.

Ministerio de Salud. (2004b). Política Nacional de Salud 2004-2015, Managua, Nicaragua.

Morgan, L. M. (1993). Community participation in health: The politics of primary care in Costa Rica. Cambridge: Cambridge University Press.

Morgan, L. M. (2001). Community participation in health: perpetual allure, persistent challenge. Health Policy and Planning, 16, 221-230. doi:10.1093/heapol/16.3.221

Muller, F. (1991). Pobreza, participación y salud: Casos Latinoamericanos [Poverty, participation and health: Latin American cases]. Medellin: Editorial Universidad de Antioquia.

Nading, A. M. (2013). "Love isn't there in your stomach": a moral economy of medical citizenship among Nicaraguan community health workers. Medical Anthropology Quarterly, 27(1), 84102. doi:10.1111/maq.12017

Renedo, A., \& Marston, C. (2015). Spaces for citizen involvement in healthcare: An ethnographic study. Sociology. doi:10.1177/0038038514544208

Rifkin, S. B. (1996). Paradigms lost: toward a new understanding of community participation in health programmes. Acta Tropica, 61, 79-92.

Rifkin, S. B. (2009). Lessons from community participation in health programmes: a review of the post Alma-Ata experience. International Health, 1, 31-36. doi:10.1016/j.inhe.2009.02.001

Roalkvam, S. (2014). Health governance in India: Citizenship as situated practice. Global Public Health, 9, 910-926. doi:10.1080/17441692.2014.941900

Roalkvam, S., \& Jani, J. (2013). Rights and obligations in national health governance. In S. Roalkvam, D. McNeill, \& S. Blume (eds.), Protecting the world's children: immunisation policies and practices (pp. 115-147). New York: Oxford University Press.

Robins, S., Cornwall, A., \& von Lieres, B. (2008). Rethinking 'citizenship' in the postcolony. Third World Quarterly, 29, 1069-1086. doi:10.1080/01436590802201048

Rogers, T. (2013, February 20 ). Is privacy at risk in Nicargua? The Nicaragua Dispatch. http://nicaraguadispatch.com/2013/02/is-privacy-at-risk-in-nicaragua/

Romero, E. G. (2010, May 16 ). De los CDS a los CPC [From CDS to CPC]. La Prensa. http://www.laprensa.com.ni/2010/05/16/politica/24768-de-los-cds-a-los-cpc

Scholl, E. A. (1985). An assessment of community health workers in Nicaragua. Social Science \& Medicine 20, 207-214.

Stokke, K. (2013). Conceptualizing the politics of citizenship. PCD Journal 5(1), 1-46.

Tesler, L. E. (2006). "Now there is no treatment for anyone": health care seeking in neo-liberal Nicaragua. (Ph.D dissertation), University of Arizona.

Vanden, H. E., \& Prevost, G. (1993). Democracy and socialism in Sandinista Nicaragua. Boulder, CO: Lynne Rienner.

Webster, N., \& Engberg-Pedersen, L. (2002). Introduction to political space. In N. Webster \& L. Engberg-Pedersen (eds.), In the name of the poor: Contesting political space for poverty reduction. New York, NY: Zed Books.

Werner, D. (1981). The village health worker: lackey or liberator? World Health Forum, 2(1), 46-68.

Wilm, J. (2011). Nicaragua, back from the dead?: An anthropological view of the Sandinista movement in the early 21st century. Tucson, AZ: New Left Notes. 